\title{
INDUCTION OF LABOR BY PROSTAGLANDIN: A REVIEW FOR INDICATIONS AND RISK FOR CESAREAN SECTION
}

\author{
PRAVATI TRIPATHY*1, PRASANNA BABY ${ }^{2}$ \\ ${ }^{1}$ Department of Nursing, SUM Nursing College, Siksha “0” Anusandhan University, Bhubaneswar, Odisha, India. ${ }^{2}$ Department of Nursing, \\ Principal, Faculty of Nursing, Sri Ramachandra University, Chennai, India. Email: pravati.tripathy@gmail.com
}

Received: 05 April 2017, Revised and Accepted: 13 June 2017

\section{ABSTRACT}

Objective: Labor induction by medication is now preferred by many obstetricians. The impact of induction remains ambiguous, although many studies and systematic reviews have been conducted. Few studies have reported for its better outcomes while other studies with poor outcomes. The objective of the study is to identify the common indications of induction and the risk of cesarean section after induction.

Methods: Various standardized databases, such as Pub Med, Scopus, and Google Scholar, were used to collect the scientific studies, where prostaglandin was used as drug of choice for induction of labor. The key words used were induction of labor, indications of induction, induction by misoprostol, induction and risk of cesarean section, etc. The survey spans over 22 years of study articles published from the year $1995-2017$.

Result: A total of 112 studies have been included to analyze the indications and risk of cesarean section. The most common indication found in most of the studies was post-term pregnancy. The risk of cesarean section varied from 3\% to 48.7\%. The common reasons for which the cesarean section was planned were, failed induction, nonprogress of labor, fetal distress, and undiagnosed CPD.

Conclusion: Most of the studies recommend induction of labor as a safer option with lower risk of c-section.

Keywords: Induction of labor, Indication of induction, Induction and c-section, Predictors of successful induction.

(C) 2017 The Authors. Published by Innovare Academic Sciences Pvt Ltd. This is an open access article under the CC BY license (http://creativecommons. org/licenses/by/4. 0/) DOI: http://dx.doi.org/10.22159/ajpcr.2017.v10i10.18937

\section{INTRODUCTION}

The labor is a unique experience for the mother and she anxiously waits for the labor pain to come naturally. But when this fails to happen, she undergoes a procedure that artificially initiates the labor which is called induction of labor. The familiarity of the procedure is slowly rising in every setting from rural to well-equipped urban hospital. There is a demand in reducing the rate of unnecessary cesarean section and improvement of fetal outcomes. This is considered when delivery is thought to be the safer option than continuing the pregnancy [1]. Prostaglandins are lipids, found in cervical fluid, and decidua that reduce the inflammatory process and dilate the cervix $[2,3]$. Prostaglandine and its group of drugs when used for ripening of cervix in case of favorable or unfavorable cervix, was effective in bringing cervical favorability and with good progress of labor by successful induction with vaginal delivery within 24 hrs without much operative delivery [4-7]. The reasons for considering induction are many and vary from obstetrician to obstetrician and from country to country [8]. The most common indication that requires induction of labor is postdated pregnancy [9-22]. Another frequently cited indication is term premature rupture of membrane $[12,13,23,24]$. Nevertheless, the hypertensive disorder remains a rare indication, rather this requires induction in higher rate $[14,20,21,25,26]$. The less frequent indications are oligohydramnios, IUGR, gestational diabetes, fetal distress, macrosomia, fetal death, decreased fetal movement, uncomplicated twins, polyhydramnios, Rh isoimmunization, chorioamnionitis, heart disease, and other fetal indications [9-14]. In a meta-analysis, it is also observed that the common indications cited by many researchers are post-term pregnancy, PROM, oligohydramnios, twins, macrosomia, preeclampsia, diabetes, and IUGR [23]. The outcomes of induction of labor are comparatively better than the spontaneous labor as reviewed from certain studies, while other studies found higher adverse outcomes associated with induction than the spontaneous labor. The causes for failure are mostly failed induction, fetal distress, undiagnosed CPD, meconeum stained liquor, nonprogress of labor, and prolonged latent phase $[10-13,27,28]$.

\section{METHODS}

To collect a good number of quality studies with best recommendations, many electronic data bases were searched. The literature was collected from databases such as Pubmed, Scopus, Science Direct, and Google Scholar. The search was based on the keywords such as induction of labor, indication of induction, failed induction, induction in post-term pregnancy, induction in PROM, induction and risk of cesarean section and others. The literature was searched from the year 1995 onward. The literatures mostly included the studies which were systematic reviews, meta-analysis, randomized controlled trial (RCT), and cohort with strong recommendations. The indication of induction was studied from all kinds of scientific literatures those have specifically mentioned the indications. The studies on elective induction and studies on other methods of induction were excluded from the search.

\section{RESULT}

The literature was compiled in an ascending order, and a total of 22 articles were analyzed for tabulating the indications for induction of labor. Table 1 shows the most frequent indications of induction in percentage.

The most common indication found by many authors is postdated pregnancy. Pregnancy when continues beyond 40 weeks is post-term pregnancy. About $7 \%$ of all pregnancies are post-term pregnancy [39]. Dean Leduce and Jarson Gardosi recorded postdates as highest indication for induction of labor $[16,40]$. Similarly, frequent indication for induction was postdates observed by Guerra et al. [10,26,41] Along with postdates, the hypertensive diseases of pregnancy are many times become the main indications for induction of labor [21]. Whereas 


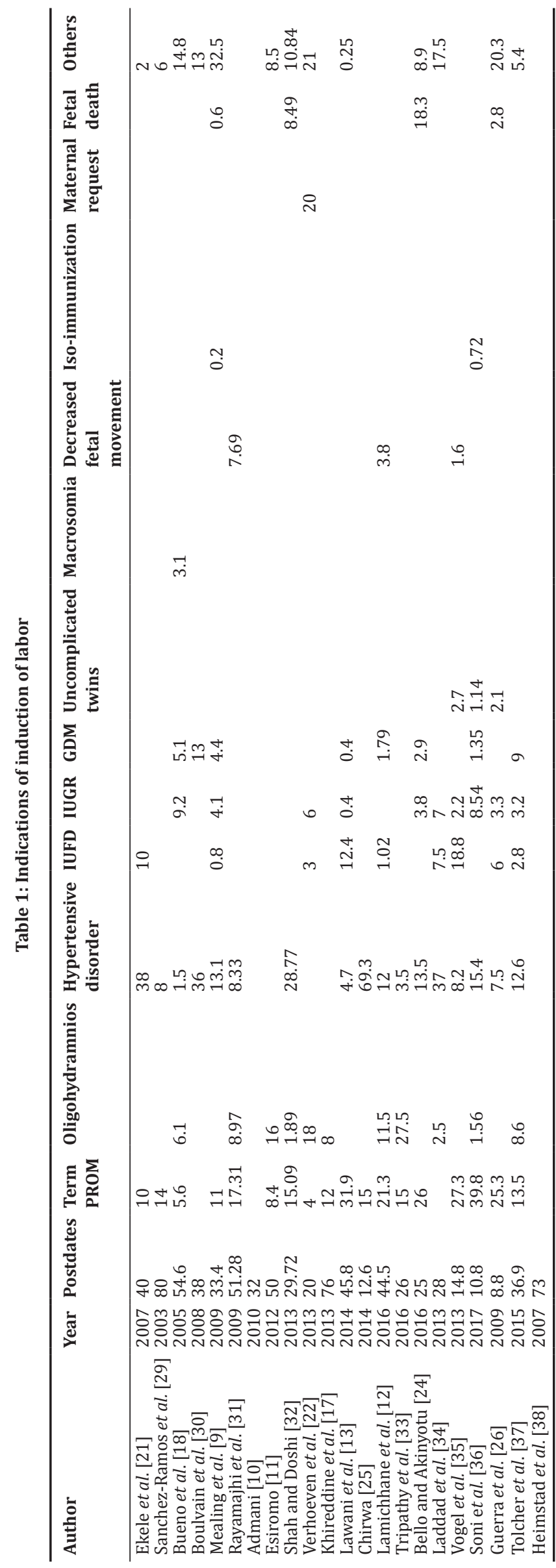

Chirwa found all three, hypertension (69.3\%), PROM (15.0\%), and postdated $(12.6 \%)$ as common indications. Similarly, Sanchez-Ramos et al. observed $80 \%$ of indications for post-term pregnancies and rest for pregnancy induced hypertension and PROM [42]. Mozurkewich et al. and Abdul and Guerra et al. reported both postdated and PROM are the common indications for induction with high-quality evidence from various studies, whereas oligohydramnios was found with moderate evidence $[26,43]$. The induction of labor is commonly indicated in prevention of prolonged pregnancy, prelabor rupture of membranes after 34 weeks, intrauterine fetal death, placental abruption, chorioamnionitis, and hypertensive disorders as stated by NICE and ACOG [44,45]. Folasade and Oriyomi also recorded $25 \%$ of indications for postdates and $26 \%$ for premature rupture of labor [24]. Lawani et al. found the major indications as postdates $(45.8 \%)$, term PROM (31.9\%), pre-eclampsia (4.7\%), and preterm PROM (3.7\%) [13]. The common causes for which the induction were carried out in the United States were pre-eclampsia and postdates pregnancies and in few cases the premature rupture of membrane [46]. When the pregnancy over 41 weeks is induced, it is associated with fewer cesarean sections compared to expectant treatment [47]. Similarly, Mishanina et al. reported that the postdates pregnancy is associated with a reduced risk of cesarean delivery [48]. When labor was induced in term PROM, the rate of cesarean section remained almost same as the compared group [32]. However, the induction in pre-eclamptic group, studied by Xenakis et al. shows higher rate of cesarean section (Table 2) [49].

The data reviewed gives a conflicting picture that there is a trends toward decreased cesarean section with good cervical dilatation after misoprostol administration and the same time it is evident that there is an increased cesarean delivery for fetal distress and undiagnosed CPD. Many studies revealed that the prostaglandin and its group of drugs when used for ripening of cervix in case of favorable or unfavorable cervix, was effective in bringing cervical favorability, good progress of labor with a successful vaginal delivery within $24 \mathrm{hrs}$ [34].

The rate of cesarean section was lowered by induction has been reported in many research studies. The successful vaginal delivery after induction was 70\% [69], 75\% [70], 89.1\% [6]. Bueno et al. found that the vaginal delivery occurred in $73.5 \%$ of women in the induction group, and the rate of cesarean delivery was $26.5 \%$ [18]. Sahanaz et al. reported vaginal delivery of $78.9 \%$ and $21.1 \%$ of cesarean section after induction of labor [56,71]. However, Admani found in her study the success rate of $50 \%$ with similar rate of failure. The similar rate was observed in the study of Pravati et al. [33]. Bello and Akinyotu found induction failed with cesarean section in about $36.5 \%$ of women. Boulvain et al. demonstrated higher cesarean section with adverse perinatal outcomes after induction of labor [30]. Induced women had significantly higher cesarean rate than the spontaneous group [5,72]. However, Boulvain et al. did not get any clear risk of c-section after induction [73]. Sometime it was observed that there are no significant differences in CS rates between the groups of vaginal misoprostol or dinoprostone after induction [74]. In other instances, there is significant difference and it was found in CS rate between in the induction group and the spontaneous group both in nulliparous women $(25.3 \%$ vs. $8.6 \%, \mathrm{p}<0.001)$ and multiparous women ( $3.8 \%$ vs. $0.3 \%, \mathrm{p}=0.002)$ [10]. Similarly, the induction is associated with a significant increase in the risk of C-section than those who delivered spontaneously [59]. Boulvain et al. demonstrated higher cesarean section with adverse perinatal outcomes after induction of labor [30]. Clader reported little higher $(28 \%)$ rate of cesarean section than the vaginal delivery $(11 \%)$ after induction of labor with misoprostol [75]. However, many studies reported higher rate of vaginal delivery after induction $(70 \%$ [69], $75 \%$ [70], 89.1\% [6]). The success rate for vaginal delivery was $70 \%$ and this rate varied little in accordance with the country or the method used [58] Alfirevic et al. study revealed that though the vaginal prostaglandins increase the chance of uterine hyperstimulation but this increase the likelihood of vaginal birth within $24 \mathrm{hrs}$ [76]. Whereas other studies shows the risk of cesarean delivery was $12 \%$ lower with labor induction than with expectant management (pooled relative 
Table 2: The rate and causes of cesarean section after induction and its' predicting factors

\begin{tabular}{|c|c|c|c|c|}
\hline Author & Year & $\begin{array}{l}\text { Rate of } \\
\text { c-section (\%) }\end{array}$ & Causes of cesarean section & Predictors of cesarean section \\
\hline Chirwa [25] & 2014 & 17 & Failed induction, fetal distress, CPD & No misoprostol \\
\hline Tolcher et al. [37] & 2015 & 29.4 & Nonreassuring heart rate & $\begin{array}{l}\text { Advanced age, short height, greater BMI, } \\
\text { weight gain, hypertension, diabetes } \\
\text { mellitus and initial cervical dilation }<3 \mathrm{~cm}\end{array}$ \\
\hline Verhoeven et al. [22] & 2013 & 3 & Failure to progress and fetal distress & $\begin{array}{l}\text { History of preterm birth, maternal height } \\
\text { and initial dilatation }\end{array}$ \\
\hline Admani [10] & 2014 & 32 & $\begin{array}{l}\text { Fetal distress, failed induction, nonprogress of } \\
\text { labor and meconium stained liquor }\end{array}$ & $\begin{array}{l}\text { Favorable Bishop score and average-sized } \\
\text { infants }\end{array}$ \\
\hline Lee et al. [50] & 2015 & 25.3 & Induction failure & Maternal age, BMI, Bishop score and parity \\
\hline Park [51] & 2007 & 14 & $\begin{array}{l}\text { Previous obstetric history, previous } \\
\text { mid-trimester loss and preterm delivery }\end{array}$ & $\begin{array}{l}\text { Earlier gestational age, previous obstetric } \\
\text { history, and preterm delivery }\end{array}$ \\
\hline Soni et al. [36] & 2017 & 30.3 & $\begin{array}{l}\text { Failed induction, fetal distress, nonprogress of } \\
\text { labor and undiagnosed CPD, malposition }\end{array}$ & \\
\hline Ezechi et al. [28] & 2004 & 27.92 & $\begin{array}{l}\text { Cephalopelvic disproportion, fetal distress, } \\
\text { prolong labor, and antepartum hemorrhage }\end{array}$ & \\
\hline Lawani et al. [13] & 2014 & 24.1 & $\begin{array}{l}\text { Fetal distress, Prolonged labor, Cephalopelvic } \\
\text { disproportion fetal distress, prolonged labor } \\
\text { and cord prolapse }\end{array}$ & \\
\hline Jayaprakash et al. [52] & 2016 & 8 & Failed induction and fetal distress & \\
\hline Bello and Akinyotu [24] & 2014 & 36.5 & & $\begin{array}{l}\text { Higher parity, later gestation and } \\
\text { misoprostol ripening }\end{array}$ \\
\hline Khan et al. [27] & 2015 & 18.1 & & $\begin{array}{l}\text { Nulliparity, poor Bishop score and } \\
\text { prolonged latent phage }\end{array}$ \\
\hline Girma et al. [53] & 2016 & 10.7 & & $\begin{array}{l}\text { Bishop score, timing of induction and } \\
\text { neonatal weight }\end{array}$ \\
\hline Marroquin et al. [54] & 2013 & 48.7 & & $\begin{array}{l}\text { Younger age, lower BMI and lower } \\
\text { maternal weight }\end{array}$ \\
\hline Danielsen et al. [55] & 2016 & 28.5 & & $\begin{array}{l}\text { Bishop score, non-reassuring fetal status, } \\
\text { failure to descend, malpresentation, } \\
\text { abruption and worsening maternal } \\
\text { medical status }\end{array}$ \\
\hline Ahmadi et al. [56] & 2016 & 21.1 & & Bishop score, parity and gestational age \\
\hline Parkes et al. [57] & 2016 & 17.1 & & $\begin{array}{l}\text { Intrauterine growth restriction, } \\
\text { oligohydramnios, placental abruption, } \\
\text { macrosomia and post-term pregnancy }\end{array}$ \\
\hline Vahratian et al. [58] & 2005 & 30 & & Unfavorable cervix \\
\hline Davey and King [59] & 2016 & 26.5 & & $\begin{array}{l}\text { Use of analgesia, higher birth weight, older } \\
\text { maternal age }\end{array}$ \\
\hline Laughon et al. [60] & 2011 & & & Bishop score \\
\hline Teixeira et al. [61] & 2012 & & & Bishop score \\
\hline Mbele et al. [20] & 2007 & & & Primigravidity \\
\hline Hurissa et al. [62] & 2015 & & & $\begin{array}{l}\text { Advanced age, primiparity, unfavorable } \\
\text { bishop score, premature rupture of } \\
\text { membrane, greater for gestation and bad } \\
\text { obstetric history }\end{array}$ \\
\hline Hatfield et al. [15] & 2007 & & & Bishop score and parity \\
\hline Grobman [63] & 2015 & & & Bishop score and parity \\
\hline Crane [64] & 2006 & & & $\begin{array}{l}\text { Maternal age, weight, height, BMI, } \\
\text { gestational age, birth weight and amniotic } \\
\text { fluid index }\end{array}$ \\
\hline Ennen et al. [65] & 2009 & & & Drug doses and cervical dilatation \\
\hline Pevnzer et al. [66] & 2009 & & & Drug doses and cervical dilatation \\
\hline Ehrenthal et al. [67] & 2010 & & & Drug doses and cervical dilatation \\
\hline Glantz [68] & 2010 & & & Drug doses and cervical dilatation \\
\hline
\end{tabular}

BMI: Body mass index

risk [RR] 0.88, 95\% confidence interval [CI] 0.84-0.93; $\mathrm{I}^{2}=0 \%$ ] [48]. Wennerholm et al. also confirmed higher c-section by expectant management rather in the induction method [77]. The cesarean delivery rate in the induction group was $36.5 \%$ compared to $34.4 \%$ in the expectant management group [78]. Women undergoing induction of labor at 39 weeks without an acute obstetric medical indication were more likely to deliver vaginally than those managed expectantly [79].
Caughey found whether it is 37 or 39 , there is no difference in cesarean section but at 40 and 41 weeks of gestation the women had a lower risk of cesarean delivery [80].

The reason of cesarean section is described by Pravati et al. as poor progress, fetal distress, cephalo-pelvic disproportion, oligohydramnios, and meconium staining [33]. Dr. Rashida found the reasons for cesarean 
as failed induction (52\%), fetal distress (23\%), and CPD (18\%) [10]. Ezechi et al. reported the reasons for failed induction with misoprostol include cephalopelvic disproportion, fetal distress, prolong labor, and antepartum hemorrhage [28] Lawani et al. also described about fetal distress, prolonged labor, cephalopelvic disproportion as reasons for cesarean section [13]. From the study of Bueno et al., it is understood that the major reasons for cesarean delivery are induction failure (34\%), nonreassuring fetal monitoring (28.9\%), pelvic disproportion (17\%), and failure to progress (14.9\%) [18].

The major predicting factor for a successful vaginal delivery after induction is the cervical factor $[20,43,52,55,60,61,81,82]$. Teixeira et al. found in their meta-analysis, the Bishop score as greater determinant of successful induction [61]. Danielsen et al. stressed that a Bishop score of more than seven should be considered before induction as Bishop score is very good predictor of successful induction [55]. Vrouenraets et al. reported that a Bishop score of 5 or less is a significant risk factor for a cesarean delivery [83] Selo-Ojeme et al. viewed that regardless of membrane status, the CS rates were high in unfavorable cervix after induction of labor [84]. Dean Leduc highlighted that induction of labor among women with poor cervical dilatation is associated with higher rate of cesarean section [16]. Bello and Akinyotu found the predicting factors for risk of cesarean section are higher parity, later gestation and misoprostol ripening. Lee et al. observed the association of the higher CS rate with lower Bishop score, advanced maternal age, nulliparity and higher body mass index (BMI). Rashida reported the success rate induction with vaginal delivery that increased with increase of age. Rebecca Dekker found interestingly the rate is rising by age that is $29.5 \%$ in age $25-29$ years to $33.0 \%$ in $30-34$ years and $38.5 \%$ in $35-39$ years and so on [85]. Rayamajhi et al. also noticed failure rate of $53.8 \%$ with advanced maternal age $>30$ years [31]. Gerli et al. also viewed that age is directly related to risk of cesarean section after a induction [86]. Hurissa et al. reported about the risk of cesarean section in association with advanced age, primiparity, unfavorable bishop score, later gestation, PROM, and bad obstetric history. The success was again related independently to cervical factors and parity [18]. Hatfield et al., Grobman, Tolcher et al. found older maternal age, shorter maternal height, greater BMI, greater weight gain during pregnancy, older gestational age, hypertension, diabetes mellitus, and initial cervical dilation as independent risk factors for increased risk of cesarean delivery $[37,62,63]$. Similarly, Crane reported the predictive factors as maternal age, weight, height, BMI, ethnicity, and socioeconomic status. Whereas Park found a single factor that is gestational age as a predictor of successful labor. Sometime the failed induction was dependent on drug doses and cervical dilatation [65-68]. Dublins reported increased cesarean delivery was associated with nulliparous rather than multiparous women with increased risk of instrumental delivery and shoulder dystocia [19]. Admani found higher rate of vaginal delivery in multipara than primipara. Lisa revealed that both the nulliparas $(27 \%)$ and multiparas $(13 \%)$ had an increased cesarean rate compared to spontaneous labor [87]. Compared to spontaneous onset of delivery, induction of labor is associated with an increased risk for emergency cesarean section among nulliparous and multiparous women [88] Alicia ault cited that the major risk associated with a failed induction at 39 weeks is cesarean delivery [89]. Park reported earlier gestational age as a significant predictive factor for failed IOL [51]. The highest chance of success was observed after induction of labor where there are prior vaginal delivery and favorable cervix [90] Timothy et al. in their systematic review found few reserearcher reporting about slower labors even after using higher doses of vaginal misoprostol [91] while other reported that high doses of oral or vaginal misoprostol are quite effective at achieving vaginal delivery. Pevzner et al. revealed that duration of labor, oxytocin requirements, and cesarean delivery rates are significantly higher with increasing BMI in prostaglandin-induced women (Table 3) [72].

The studies by meta-analysis, RCT and many other methods found different rate of risk of cesarean section at the end of the induction of labor. The risk of cesarean section depends on maternal factors such as age, parity, BMI, cervical score, baby size, medical, and obstetrical conditions complicating pregnancy. However, most of the studies found the induction is associated with more cervical ripening and successful vaginal delivery $[6,14,69-70,76,98]$. While few studies found the induction results in higher rate of cesarean delivery compared to expectant management $[22,19,104]$.

\section{Summary}

This study tried to highlight various indications for which an induction of labor is decided for a woman. The common indications were postterm pregnancy, term PROM, hypertensive disorders, intrauterine fetal distress, fetal death, gestational diabetes, and other fetal indications. Among these, the most common indication was postdated pregnancy. The failure of induction with cesarean section was varied from $3 \%$ to $48.7 \%$. However, most of the studies found higher rate of successful delivery after induction. The reason for which cesarean section was

Table 3: The net outcome after induction of labor

\begin{tabular}{|c|c|c|c|}
\hline Author & Year & Research design & Net outcome (rate of cesarean section) \\
\hline Mishanina et al. [48] & 2014 & Systematic review and meta-analysis & Decreased \\
\hline Hofmeyr and Gulmezoglu [92] & 2001 & Systematic review & Decreased \\
\hline Wood et al. [93] & 2014 & Meta-analysis & Decreased \\
\hline Gulmezoglu et al. [47] & 2006 & Systematic review & Decreased \\
\hline Gulmezoglu et al. [94] & 2012 & Systematic review & Decreased \\
\hline Sanchez Ramos et al. [29] & 2003 & Systematic review & Decreased \\
\hline Alfirevic et al. [76] & 2014 & Systematic review & Decreased \\
\hline Boulvain et al. [30] & 2008 & Systematic review & Decreased \\
\hline Vogel et al. [35] & 2013 & Systematic review & Decreased \\
\hline Crowley [96] & 2000 & Systematic review & No difference \\
\hline Boulvain et al. [73] & 2016 & Systematic review & Not clear \\
\hline Guerra et al. [26] & 2009 & Secondary analysis & Decreased \\
\hline Cheng [97] & 2008 & RCT & Decreased \\
\hline Koopmans et al. [98] & 2009 & RCT & Decreased \\
\hline Pennel et al. [99] & 2009 & RCT & Increased \\
\hline Marry et al. [37] & 2015 & Cohort & Decreased \\
\hline Yeast et al. [102] & 1999 & Cohort & Decreased \\
\hline Nooh et al. [103] & 2005 & Retrospective & Decreased \\
\hline Dubline et al. [19] & 2000 & Cohort & Increased \\
\hline Johnson et al. [104] & 2003 & Cohort & Increased \\
\hline Verhoeven et al. [22] & 2012 & Case control & Increased \\
\hline
\end{tabular}


done were failed induction, fetal distress, meconium stained liquor, undiagnosed CPD, and nonprogress of labor. The factors independently predicted the risk of cesarean section were age of mother, parity, BMI, cervical factors, indications, doses of drug and weight of baby. Most of the systematic reviews showed decreased rate of c-section after induction in term pregnancy. Hence, it is clear from the findings that induction of labor is beneficial in reducing the risk of cesarean section with better perinatal outcomes.

\section{REFERENCES}

1. Mckinnon AO, Squires EL, Vaala WE, Varner DD, McDonnell S. Abnormal sexual behavior In Equine Reproduction. West Sussex, UK: Wiley Blackwell; 2011. p. 1407-12.

2. Kandhaswamy A, Rangan S, Ahmed I, Meena KS. Synthesis, in silico docking and admet studies of arylacetic acid derivatives as prostaglandin endoperoxide $\mathrm{H}$ synthase-2 inhibitors. Asian J Pharm Clin Res 2017;10(4):68-72.

3. Bhupesh CS, Rohit B, Kalyani D. Analgesic activity of hydroalcoholic extract of aerial parts of malvastrum coromandelianum. Asian J Pharm Clin Res 2016;9(5):146-9.

4. Wing DA, Gaffaney CA. Vaginal misoprostol administration for cervical ripening and labor induction. Clin Obstet Gynecol 2006;49(3):627-41.

5. Kelly AJ, Malik S, Smith L, Kavanagh J, Thomas J. Vaginal prostaglandin (PGE2 and PGF2a) for induction of labour at term. Database Syst Rev 2009;4:CD003101.

6. Abbasi N, Danish N, Shakoor F, Parveen Z, Bilal SA. Effectiveness and safety of vaginal misoprostol for induction of labour in unfavourable cervix in $3^{\text {rd }}$ trimester. J Ayub Med Coll Abbottabad 2008;20(3):33-5.

7. Crane JM, Butler B, Young DC, Hannah ME. Misoprostol compared with prostaglandin E2 for labour induction in women at term with intact membranes and unfavourable cervix: A systematic review. BJOG 2006;113(6):1366-76.

8. Gulmezoglu AM, Crowther CA, Middleton P, Heatley E. Induction of labour for improving birth outcomes for women at or beyond term. Cochrane Database Syst Rev 2012;6:Cd004945.

9. Mealing NM, Roberts CL, Ford JB, Simpson JM, Morris JM, Aust N Z. J Obstet Gynaecol. 2009; 49(6):599-605.

10. Admani R. Predictors of Successful Induction of Labor in Post Term Pregnancies at Kenyatta National Hospital; 2014. Available from: http://www.obsgyn.uonbi.ac.ke/sites/default/files/chs/medschool// Dr\%20Rashida\%20Admani.pd.

11. Esiromo M. Maternal and Fetal Outcomes among Women at or Near Term Undergoing Pharmacological Induction of Labor at KNH. M.Med, Thesis U.O.N; 2011. Available from: http://www.erepository.uonbi. ac.ke:8080//Esiromo Outcomes\%20Of\%20Pharmacological\%20I.

12. Lamichhane S, Subedi S, Banerjee B, Bhattara R. Outcome of induction of labor. A prospective study. Ann Int Med Dent Res 2016;2(6):1-5.

13. Lawani OL, Onyebuchi AK, Iyoke CA, Okafo CN, Ajah LO. Obstetric outcome and significance of labour induction in a health resource poor setting. Obstet Gynecol Int 2014. DOI: 10.1155/2014/419621.

14. Michelson KA, Carr DB, Easterling TR. The impact of duration of labor induction on cesarean rate. Am J Obstet Gynecol 2008;199(3):299.e1-4.

15. Hatfield AS, Sanchez-Ramos L, Kaunitz AM. Sonographic cervical assessment to predict the success of labor induction: A systematic review with metaanalysis. Am J Obstet Gynecol 2007;197(2):186-92.

16. Leduc D, Ottawa ON, Biringer A, Toronto ON, Lee L, Vancouver BC, et al. Induction of labour. J Obstet Gynaecol Can 2013;35(9):840-60.

17. Khireddine I, Le Ray C, Dupont C, Rudigoz RC, Bouvier-Colle MH, Deneux-Tharaux C. Induction of labor and risk of postpartum hemorrhage in low risk parturients. PLoS One 2013;8(1):e54858.

18. Bueno B, San-Frutos L, Pérez-Medina T, Barbancho C, Troyano J, Bajo J. The labor induction: Integrated clinical and sonographic variables that predict the outcome. J Perinatol 2007;27(1):4-8.

19. Dublin S, Lydon-Rochelle M, Kaplan RC, Watts DH, Critchlow CW. Maternal and neonatal outcomes after induction of labor without an identified indication. Am J Obstet Gynecol 2000;183(4):986-94.

20. Mbele AM, Makin JD, Pattinson RC. Can the outcome of induction of labor with oral misoprostol be predicted. S Afr Med J 2007;97(4):289-92.

21. Ekele BA, Nnadi DC, Gana MA, Shehu CE, Ahmed Y, Nwobodo EI. Misoprostol use for cervical ripening and induction of labour in a Nigerian teaching hospital. Niger J Clin Pract 2007;10(3):234-7.

22. Verhoeven CJ, van Uytrecht CT, Porath MM, Mol BW. Risk factors for cesarean delivery following labor induction in multiparous women. J Pregnancy 2013;2013:6.

23. Mozurkewich E, Chilimigras J, Koepke E, Keeton K, King VJ.
Indications for induction of labor: A best-evidence review. Am J Matern Child Nurs 2009;34:6.

24. Bello FA, Akinyotu OO. Predictors of successful induction of labor at a tertiary obstetric service in Southwest Nigeria. Trop J Obstet Gynaecol 2016;33(2):143-8

25. Chirwa M. Factors Associated with Failed Induction of Labor at the University Teaching Hospital. Lusaka: Medical Thesis; 2014

26. Guerra GV, Cecatti JG, Souza JP, Faúndes A, Morais SS, Gülmezoglu AM, et al. Factors and outcomes associated with the induction of labour in Latin America. BJOG 2009;116(3):1762-72.

27. Khan NB, Ahmed I, Malik A, Sheikh L. Factors associated with failed induction of labour in a secondary care hospital. J Pak Med Assoc 2012;62(1):6-10

28. Ezechi OC, Kalu BK, Njokanma FO, Nwokoro CA, Okeke GC. Vaginal misoprostol induction of labor: A Nigerian hospital experience. J Obstet Gynaecol 2004;24(3):239-42.

29. Sanchez-Ramos L, Olivier F, Delke I, Kaunitz AM. Labor induction versus expectant management for postterm pregnancies: A systematic review with meta-analysis. Obstet Gynecol 2003;101(6):1312-8.

30. Boulvain M, Kelly A, Irion O. Intracervical prostaglandins for induction of labour. Cochrane Database Syst Rev 2008;1:CD006971.

31. Rayamajhi RT, Karki C, Shrestha N, Padhye SM. Indication for labour induction and predictors for failed induction at KMCTH. Kathmandu Univ Med J (KUMJ) 2009;7(25):21-5.

32. Shah K, Doshi H. Premature rupture of membrane at term: Early induction versus expectant management. J Obstet Gynaecol India 2012;62(2):172-5

33. Tripathy P, Pati T, Baby P, Mohapatra SK. Prevalence and predictors of failed. Induction. Int J Pharm Sci Rev Res 2016;39(2):189-94.

34. Laddad MM, Kshirsagar NS, Karale AV. A prospectiverandomized comparative study of intra-cervical Foley's catheter insertion versus PGE2 gel for pre-induction cervical ripening. Int J Reprod Contracept Obstet Gynecol 2013;2(2):217-20.

35. Vogel JP, West HM, Dowswell T. Titrated oral misoprostol for augmenting labour to improve maternal and neonatal outcomes. Cochrane Database Syst Rev 2013;9:CD010648.

36. Soni K, Subudhi K, Mishra B, Gouda BC, Chaudhary S. Maternal and perinatal outcome in induction of labor: A comparative study. Sch J Appl Med Sci 2017;5(1D):273-81.

37. Tolcher MC, Holbert MR, Weaver AL, McGree ME, Olson JE, El-Nashar SA, et al. Predicting cesarean delivery after induction of labor among nulliparous women at term. Obstet Gynecol 2015;126(5):1059-68.

38. Heimstad R, Skogvoll E, Mattsson LA, Johansen OJ, Eik-Nes SH, Salvesen KA. Induction of labor or serial antenatal fetal monitoring in postterm pregnancy: A randomized controlled trial. Obstet Gynecol 2007;109(3):609-17.

39. Martin JA, Hamilton BE, Sutton PD, Ventura SJ, Mathews TJ, Kirmeyer S, et al. Births: Final data for 2007. Natl Vital Stat Rep 2010;58(24):1-85

40. Gardosi J, Vanner T, Francis A. Gestational age and induction of labor for prolonged pregnancy. Br J Obstet Gynaecol 1997;104(7):792-7.

41. Paliulyte $V$, Ramašauskaite $D$. Labour induction in postdate pregnancy: When to start - At week 40 or 41 of gestation? Acta Med Lituanica 2010;17(1-2):11-6.

42. Sanchez-Ramos L, Kaunitz A. Induction of labor: Update and review. Glob Libr Women's Med 2009. DOI: 10.3843/GLOWM.10130.

43. Roman H, Verspyck E, Vercoustre L, Degre S, Col JY, Firmin JM, et al. Does ultrasound examination when the cervix is unfavorable improve the prediction of failed labor induction? Ultrasound Obstet Gynecol 2004;23:357-62

44. National Institute for Health and Care Excellence. Induction of Labor. NICE Guideline CG70, Published July; 2008. Available from: http:// www.nice.org.uk/guidance/cg70/chapter/1-recommendations.

45. American College of Obstetricians and Gynecologists. Induction of labor. ACOG practice bulletin 107. Obstet Gynecol 2009;114:386-97.

46. Lydon-Rochelle MT, Cárdenas V, Nelson JC, Holt VL, Gardella C, Easterling TR. Induction of labor in the absence of standard medical indications: Incidence and correlates. Med Care 2007:45(6):505-12.

47. Gülmezoglu AM, Crowther CA, Middleton P. Induction of labour for improving birth outcomes for women at or beyond term. Cochrane Database Syst Rev 2006; 4:CD004945.

48. Mishanina E, Rogozinska E, Thatthi T, Uddin-Khan R, Khan KS, Meads C. Use of labor induction and risk of cesarean delivery: A systematic review and meta-analysis. Can Med Assoc J 2014;186(9):665-73

49. Xenakis EM, Piper JM, Field N, Conway D, Langer O. Preeclampsia: Is 
induction of labor more successful? Obstet Gynecol 1997;89(4):600-3.

50. Lee HR, Kim MN, You JY, Choi SJ, Oh SY, Roh CR, et al. Risk of cesarean section after induced versus spontaneous labor at term gestation. Obstet Gynecol Sci 2015;58(5):346-52.

51. Park KH. Transvaginal ultrasonographic cervical measurement in predicting failed labor induction and cesarean delivery for failure to progress in nulliparous women. J Korean Med Sci 2007;22(4):722-7.

52. Jayaprakash S, Muralidhar L, Venkatesh S. Intracervical PGE2 gel for induction of labour in patients with prelabour rupture of membranes with unfavorable cervix after 34 weeks period of gestation. Int J Reprod Contracept Obstet Gynecol 2016;5(5):1418-22.

53. Girma W, Tseadu F, Wolde M. Outcome of induction and associated factors among term and post-term mothers managed at Jimma university specialized hospital: A two years' retrospective analysis. Ethiop J Health Sci 2016;26(2):121-30.

54. Marroquin GA, Tudorica N, Salafia CM, Hecht R, Mikhail M. Induction of labor at 41 weeks of pregnancy among primiparas with an unfavorable Bishop score. Arch Gynecol Obstet 2013;288(5):989-93.

55. Danielsen C, White D, Hunter G, Olender M, Davis G. Using Bishop Score to Predict Labor Induction Time and Failure Rate; 2016. Available from: http://www.rowan.edu/som/education/graduate_medical/xDanielsen_Poste.

56. Ahmadi S, Rahmani E, Motamed N, Ghorbanpoor M, Maneshi H. Bishop score predictive value in success of induced labor process among full term pregnant women referred to Persian Gulf Martyrs' Hospital in Bushehr in 2013. Iran South Med J 2016;19(4):620-8.

57. Parkes I, Kabiri D, Hants Y, Ezra Y. The indication for induction of labor impacts the risk of cesarean delivery. J Matern Fetal Neonatal Med 2016;29(2):224-8.

58. Vahratian A, Zhang J, Troendle JF, Sciscione AC, Hoffman MK. Labor progression and risk of cesarean delivery in electively induced nulliparas. Obstet Gynecol 2005;105(4):698-704.

59. Davey MA, King J. Caesarean section following induction of labour in uncomplicated first births-a population-based cross-sectional analysis of 42,950 births. BMC Pregnancy Childbirth 2016;16:92.

60. Laughon SK, Zhang J, Troendle J, Sun L, Reddy UM. Using a simplified Bishop score to predict vaginal delivery. Obstet Gynecol 2011;117(4):805-11.

61. Teixeira C, Lunet N, Rodrigues T, Barros H. The Bishop Score as a determinant of labour induction success: A systematic review and metaanalysis. Arch Gynecol Obstet 2012;286(3):739-53.

62. Hurissa BF, Geta M, Belachew T. Prevalence of failed induction of labor and associated factors among women delivered in hawassa public health facilities, Ethiopia. J Womens Health Care 2015;4:253.

63. Grobman WA. Predictors of induction success. Semin Perinatol 2012;36(5):344-7.

64. Crane JM. Factors predicting labor induction success: A critical analysis. Clin Obstet Gynecol 2006;49(3):573-84

65. Ennen CS, Bofill JA, Magann EF, Bass JD, Chauhan SP, Morrison JC. Risk factors for cesarean delivery in preterm, term and post-term patients undergoing induction of labor with an unfavorable cervix. Gynecol Obstet Invest 2009;67(2):113-7.

66. Pevzner L, Rayburn WF, Rumney P, Wing DA. Factors predicting successful labor induction with dinoprostone and misoprostol vaginal inserts. Obstet Gynecol 2009;114:261-7.

67. Ehrenthal DB, Jiang X, Strobino DM. Labor induction and the risk of a cesarean delivery among nulliparous women at term. Obstet Gynecol 2010;116(1):35-42.

68. Glantz JC. Term labor induction compared with expectant management. Obstet Gynecol 2010;115(1):70-6.

69. Rouzi AA, Alsahly N, Alamoudi R, Almansouri N, Alsinani N, Alkafy S, et al. Randomized clinical trial between hourly titrated and 2 hourly static oral misoprostol solution for induction of labor. Am J Obstet Gynecol 2017;216(4):405.e1-405.e6.

70. Blackwell SC, Redman ME, Tomlinson M, Landwehr JB Jr, Tuynman M, Gonik B, et al. Labor induction for the preterm severe pre-eclamptic patient: Is it worth the effort? J Matern Fetal Med 2001;10(5):305-11.

71. de la Torre S, Gilson GJ, Flores S, Curet LB, Qualls CE, Rayburn WF. Is high-dose misoprostol able to lower the incidence of cesarean section? A randomized controlled trial. J Matern Fetal Med 2001;10(2):85-90.

72. Pevzner L, Powers BL, Rayburn WF, Rumney P, Wing DA. Effects of maternal obesity on duration and outcomes of prostaglandin cervical ripening and labor induction. Obstet Gynecol 2009;114(6):1315-21.

73. Boulvain M, Irion O, Dowswell T, Thornton JG. Induction of labour at or near term for suspected fetal macrosomia. Cochrane Database Syst Rev 2016;5:CD000938.
74. Moodley J, Venkatachalam S, Songca P. Misoprostol for cervical ripening at and near term - A comparative study. S Afr Med J 2003;93(5):371-4.

75. Calder AA, Loughney AD, Weir CJ, Barber JW. Induction of labour in nulliparous and multiparous women: A UK, multicentre, open-label study of intravaginal misoprostol in comparison with dinoprostone. BJOG 2008;115(10):1279-88.

76. Alfirevic Z, Aflaifel N, Weeks A. Oral misoprostol for induction of labour. Cochrane Database Syst Rev 2014;6:CD001338.

77. Wennerholm UB, Hagberg H, Brorsson B, Bergh C. Induction of labor versus expectant management for post-date pregnancy: Is there sufficient evidence for a change in clinical practice? Acta Obstet Gynecol Scand 2009;88(1):6-17.

78. Daskalakis G, Zacharakis D, Simou M, Pappa P, Detorakis S, Mesogitis $\mathrm{S}$. Induction of labor versus expectant management for pregnancies beyond 41 weeks. J Matern Fetal Neonatal Med 2014;27(2):173-6.

79. Palatnik A, Grobman WA. Induction of labor versus expectant management for women with a prior cesarean delivery. Am J Obstet Gynecol 2015;212(3):358.e1-6.

80. Caughey AB. Induction of labour: Does it increase the risk of cesarean delivery? BJOG 2014;121:658-61.

81. Yang SH, Roh CR, Kim JH. Transvaginal ultrasonography for cervical assessment before induction of labor. J Ultrasound Med 2004;23(3):375-82.

82. Abdul MA, Ibrahim UN, Yusuf MD, Musa H. Efficacy and safety of misoprostol in induction of labour in a Nigerian tertiary hospital. West Afr J Med 2007;26(3):213-6.

83. Vrouenraets FP, Roumen FJ, Dehing CJ, van den Akker ES, Aarts MJ, Scheve EJ. Bishop score and risk of cesarean delivery after induction of labor in nulliparous women. Obstet Gynecol 2005;105(4):690-7.

84. Selo-Ojeme DO, Pisal P, Lawal O, Rogers C, Shah A, Sinha S. A randomised controlled trial of amniotomy and immediate oxytocin infusion versus amniotomy and delayed oxytocin infusion for induction of labour at term. Arch Gynecol Obstet 2009;279(6):813-20.

85. Dekker R. Maternal Age or Pregnancy at Age 35 or Older. Available from: http://www.evidencebasedbirth.com/advanced-maternal-age. [Last accessed on 2016 Mar 28].

86. Gerli S, Favilli A, Giordano C, Bini V, Di Renzo GC. Single indications of induction of labor with prostaglandins and risk of cesarean delivery: A retrospective cohort study. J Obstet Gynaecol Res 2013;39:926-31.

87. Levine LD, Hirshberg A, Srinivas SK. Term induction of labor and risk of cesarean delivery by parity. J Matern Fetal Neonatal Med 2014;27(12):1232-6.

88. Thorsell M, Lyrenäs S, Andolf E, Kaijser M. Induction of labor and the risk for emergency cesarean section in nulliparous and multiparous women. Acta Obstet Gynecol Scand 2011;90(10):1094-9.

89. Ault A. American Congress of Obstetricians and Gynecologists (ACOG) 2016 Annual Clinical Meeting, Medscape Medical News Conference News, Induction at 39 Weeks Is Better for Mother and Baby, May 17; 2016.

90. Wing DA. Cervical Ripening and Induction of Labor in Women with a Prior Cesarean Delivery. Available from: http://www.uptodate. $\mathrm{com} /$ contents/cervicalripening-and-induction-of-labor-in-womenwith-a-prior-cesarean-delivery\#H626360154. [Last updated on 2016 Sep 22].

91. Kundodyiwa TW, Alfirevic Z, Weeks AD. Low-dose oral misoprostol for labor induction, a systematic review. Obstet Gynecol 2009;113(2):374-83.

92. Hofmeyr GJ, Gulmezoglu AM. Vaginal misoprostol for cervical ripening and labor induction in late pregnancy. Cochrane Database Syst Rev 2000;2:CD000941.

93. Wood S, Cooper S, Ross S. Does induction of labor increase the risk of caesarean section? A systematic review and meta-analysis of trials in women with intact membranes. BJOG Int J Obstet Gynaecol 2014;121(6):674-85

94. Gülmezoglu AM, Crowther CA, Middleton P, Heatley E. Induction of labor for improving birth outcomes for women at or beyond term. Cochrane Database Syst Rev 2012;6:CD004945.

95. Alfirevic Z, Howarth G, Gaussmann A. Oral misoprostol for induction of labor with a viable fetus. Cochrane Database Syst Rev 2000;2:CD001338

96. Crowley P. Interventions for preventing or improving the outcome of delivery at or beyond term. Cochrane Database Syst Rev 2000;2:CD000170

97. Cheng SY, Ming H, Lee JC. Titrated oral compared with vaginal misoprostol for labor induction: A randomized controlled trial. Obstet Gynecol 2008;111(1):119-25. 
98. Koopmans CM, Bijlenga D, Groena H, Vijgen SM, Aarnoudse JG, Bekedam DJ, et al. Induction of labor versus expectant monitoring for gestational hypertension or mild pre-eclampsia after 36 weeks' gestation (HYPITAT): A multicentre, open-label randomised controlled trial. Lancet 2009;374(9694):979-88.

99. Pennell CE, Henderson JJ, O'Neill MJ, McChlery S, Doherty DA, Dickinson JE. Induction of labour in nulliparous women with an unfavourable cervix: A randomised controlled trial comparing double and single balloon catheters and PGE2 gel. BJOG 2009;116(11):1443-52.

100. Bhutto A, Mahesh A, Khan A. Rectal misoprostol versus intravenous syntometrine in active management of third stage of labor in low risk women. Med Channel J 2013:4:40-43.
101. Hermus MA, Verhoeven CJ, Mol BW, de Wolf GS, Fiedeldeij CA. Comparison of induction of labour and expectant management in postterm pregnancy: A matched cohort study. J Midwifery Womens Health 2009;54(5):351-6.

102. Yeast JD, Jones A, Poskin M. Induction of labor and the relationship to cesarean delivery: A review of 7001 consecutive inductions. Am J Obstet Gynecol 1999;180(3):628-33.

103. Nooh A, Baghdadi S, Raouf S. Induction of labor: How close to the evidence-based guidelines are we? J Obstet Gynaecol 2005;25(5):451-4.

104. Johnson DP, Davis NR, Brown AJ. Risk of cesarean delivery after induction at term in nulliparous women with an unfavorable cervix. Am J Obstet Gynecol 2003;188(6):1565-9. 